\title{
From the Desk of
}

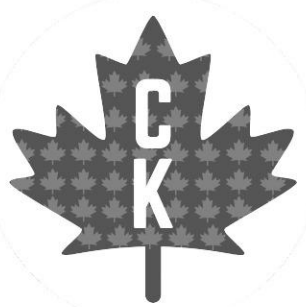

\section{the Editorial Board}

Often in writing such introductions or statements that ought to summarize the long journey towards completing an inaugural journal issue, there is a marked tendency to turn to platitudes and/or witty summations. And while we are conscious of that fact, it is to one such witticism we turn as we reflect on our path here: 'it takes a village'. In the beginning, we set out to provide a space for undergraduate students to engage in critical discourse that speaks to the contemporary Canadian moment. There is a sense - although almost every generation tends to feel this keenly - that we are living through the turn of an era, tumultuous times that portend great transformation, and require new ways of organizing our ideas and our interactions.

Our name choice was in part to reflect this, 'contemporary' was about the moment we found ourselves in, but 'kanata' was about reimagining Canada. The Iroquois word from which 'Canada' emerged is said to mean 'the settlement' or 'the village', and that was what we were trying to evoke. A space for critical discourse that began from a precise understanding of community. One that would draw on our commonality as Glendon students who have spent four-plus years studying and researching in a close-knit campus. It remains in many ways our hope for the future. And so, when we say it takes a village, we are not just reflecting on the path it took to get us here, but also on the path we wish to emerge from our work. We practice gratitude to all: those who have come before making this possible (Indigenous caretakers, our ancestors), those who are with us now upholding our vision (our faculty, staff, and volunteers), and those who will join us (altaeri saeculo).

While we decided not to impose a theme on our article submissions, one nonetheless arose from the papers submitted: marginalities and marginalized bodies. In "'How Do You Criticize a Life Story?': Form, Trauma, and Memoir in Canada Reads 2020", T. Brown explores how the Canadian Broadcasting Corporation utilizes the marginal genre of memoir often thought of as 'lowbrow' to create emotional connections that emphasize empathy and build paths for revisiting personal trauma and memory. Continuing the conversation on less prominent literary forms, C. Gardner takes Madeleine Thien's Do Not Say We Have Nothing as a starting point for analyzing the reciprocal link between text and image. In the paper, "Mash-up, Smash-up: Mixing Genres and Mediums to Rewrite History in Do Not Say We Have Nothing", the authors posits that such a collision of genres might allow for previously omitted and marginal voices within historical accounts to become more audible.

R. Ghanem turns the conversation towards marginal bodies and their encounter with the Canadian borders. In "Canada A Long Way to Go: The Designated Country of Origin Policy and Refugee Protection", the Designated Country of Origin policy is evaluated within a larger context of other immigration regulations and human rights concerns as a tool that undermines refugee protection. R. Lovering's "Graphic Reminders: Confronting Colonialism in Canada through Betty: The Helen Betty Osborne Story" invites the reader to consider a form that moves between text and images, much like C. Gardner's paper. Here, however, the form being analyzed is that of a graphic novel. The paper argues for a reading of Canadian history through its central text as one that has long held patterns of racism against Indigenous women.

J. Marsella continues this dialogue on racism against Indigenous women in "Examining the Subjugation of Indigenous Women through Community Partnerships with Extractive Industries". Here, the case is made that extractive industries are enmeshed in the history of Canadian colonization and patriarchy, disproportionately impacting Indigenous women, prompting an evaluation of such corporate projects and the rationale underpinning them. S. Topp as the final article's author brings our conversation full circle to the home city of our journal. Tackling Toronto and specifically the Runnymede-Bloor West Village community, Topp calls for greater awareness of the effects of gentrification on cities as a precursor to segregation along racial and class lines. 


\section{From the Desk of}

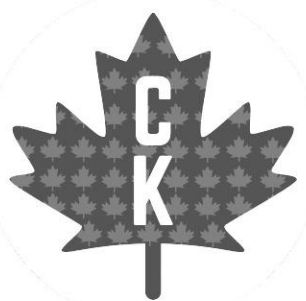

\section{the Editorial Board}

Part of our resistance to the power structures that academia and scholarship reify, required us to create avenues for other forms of knowledge-making within our pages that depart from the traditional essay structure: cartoons, poetry, personal and visual essays. In our Alternative Epistemologies section, a found poem entitled "we're all in this together" by M. Rykov invites us to consider - in response to our call along these thematic lines - (in)visibility and primacy accorded to objects and bodies, and the meanings behind this ordering. We remain immensely proud of the offerings of our first issue and invite you to read and engage with the discourses they interact with.

Thank you,

B. Cohen

A. González

J. Oduro

D. Vasquez

\& M. Joseph 